\title{
Conceptual Review of Rethinking Marine Tourism Visit Intention from Word of Mouth, Destination Image dan Destination Branding
}

\author{
A Y A Fianto ${ }^{1}$, C Candraningrat ${ }^{2}$ \\ \{ayanu@stikom.edu ${ }^{1}$, candra@stikom.edu ${ }^{2}$ \} \\ ${ }^{1,2}$ Institut Bisnis dan Informatika Stikom Surabaya, Indonesia
}

\begin{abstract}
The purpose of this study was to provide an in-depth review of visit intentions through word of mouth (WOM) variables, goal drawings, and destination brands on coastal attractions. Furthermore, analyzing how word of mouth (WOM), destination image, and destination brand on coastal tourism objects can help increase tourist intention or commonly referred to as tourist visits which are key in competing in the tourism industry. The literature review is carried out through five stages, namely scope, keyword identification, previous research, the results of previous studies, and the purpose of further research. The results of this review show that word of mouth, destination image and destination branding are the keys that must be understood, implemented and maintained by managers of marine tourism objects in increasing the intention of visiting tourists.
\end{abstract}

Keywords: Word of Mouth, Destination Image, Destination Branding

\section{Introduction}

Studies in the field of consumer behavior, especially in the realm of tourism, have developed rapidly. This is due to an increase in the need for insight into tourist intention in tourists as a basis for developing strategies to win the market competition. According to research[1]-[3]that visiting intention is also influenced by word of mouth (WOM), destination image, and destination branding factors.

Word of mouth (WOM) is a process of information exchange that occurs between many people related to a product that occurs freely without being tied to the company [4]. Destination image is interpreted as a manifestation of the overall appearance that arises from one's prejudices, knowledge, imagination, emotional thoughts towards a tourist spot [5].

Whereas destination branding is defined as a name, symbol, logo, or something else that is used to explain and differentiate a tourist place from one another and can also be explained as a promising thing related to a tourist place because of the uniqueness possessed by us. to increase and even retain tourist memories of a tourist spot [6].

Therefore, it is necessary to carry out research that examines tourists visiting intention in a tourist attraction that is influenced by factors of word of mouth, destination image and destination branding. This research is carried out through a literature review that refers to the topic specified. 


\section{Literature Review}

\subsection{Visit Intention}

The intention is defined as a person's intention in products, both goods, and services [7]. The reason for someone's intention in the product is because of various things including (1) a feature that is because the product has a unique and even attractive appearance; (2) benefits, namely because the product provides benefits to a particular person and (3) information that is because the product is the result of the influence of other parties who have previously used or bought.

The intentionof a person arises consciously so that it has an impact on the decision to have a favored goal [8]. Intention can also be understood as a form of intrinsic motivation. The positive influence of this intention makes a person try things like pleasure, happiness, and joy [9]. Based on an explanation related to this intention it can be understood that intention is influenced by perception and also motivation [8].

In addition, [10] suggest that there are external factors that influence a person's intentions. First, the attitude of other people is how much influence other people have on the alternative to be chosen by the consensus, both positive and negative influences. Second, an unexpected condition is an event that immediately emerges so that it certainly affects someone's intentions.

In this case, the intention in visiting is the desire in one's heart to act or have something that comes from a stimulus to do so [11]. Whereas according to [12] that visiting intention is the desire in a person both individuals and groups to visit a tourist spot. According to [3], intention in visiting has several special characteristics, namely (1) Individual, so that there is a difference between the intentions of one person to another; (2) Triggering injustice; (3) Closely related to motivation and influence and influence by motivation; and (4) Always change according to needs and experience.

Visiting intentions can be measured through three indicators, including (1) Cognition, that is, tourists' beliefs about tourist attractions obtained from thought processes; (2) Emotions, namely the feeling of attraction of tourists to tourist attractions; and (3) Konasi, which is a business related to the intention to make a visit to a tourist place.

\subsection{Word of Mouth}

Word of Mouth (WOM) is a process of exchange of information that occurs between many people related to a product that occurs freely without being bound by the company [4]. While according to [1] that WOM is communication that occurs in individuals or companies in recommending, discussing, and selling certain brands to other parties. According to [13] that consumers receive and respond to WOM during conditions (1) Lack of information obtained to make choices; (2) Products are very broad and difficult to assess through criteria measurement; (3) Lack of ability to assess products; (4) Other sources of low quality information; (5) Affordability of other people because it is a material for consultation and more efficient and effective; (6) Social ties between the giver and recipient of information; and (7) Someone needs adequate recommendations from the social environment. 
[14] explains that WOM is likened to a virus, which is easy to move anywhere in a short time. This WOM can be either positive or negative. This depends on how it is spread [14]. If WOM is brought about it has a positive impact, meaning the spread that occurs on good things. And vice versa, if it is caused a negative impact means the spread that occurs regarding bad things [14].A positive example of WOM is that if consumers feel satisfied with the product because the product has high quality, the price is appropriate and the evidence of advertising results displayed in various media, consumers will favor the product and influence others to buy or use it.These three things are very important to note for every company, in addition to creating a positive WOM it is also used as a key to competitive advantage [15].

According to[4] that WOM information consists of three types, among others (1) expert to expert is a dissemination of information which is included in a very important category, quality and as a trigger which occurs between a person who speaks to an expert according to his field related certain products; (2) expert to peer is a dissemination of information that functions as a reference which occurs between a layman in seeking information and recommendations for a particular product with an expert in his field; (3) peer to peer is a spread that is included in the standard category which occurs between someone who is early in making decisions related to certain products with people who are already in the product.

According to [1] that there are several feedbacks that occur after the dissemination of WOM information, among others (1) consumption of messages, namely the results of the communication process related to the things needed; (2) information retrieval which is the result of the communication process used as a reference; (3) conversion which is the result of a communication process which is able to change someone who does not know to be aware of the beginning; (4) resubmission, namely and (5) recreation of messages, namely the continuous dissemination of information from someone who has received WOM to others.

WOM has several functions. The function of WOM according to [16] is as a trigger for a consumer behavior that exists within a person, as forming social relations and as a manifestation of consumer behavior from the past. Word of mouth can be measured by two indicators (1) Volume, which is how often people talk about or recommend about a product; (2) Dispersion, which is the level was taking place in product conversations is in broad communication.

\subsection{Destination Image}

Destination image is a form of overall appearance that arises from one's prejudice, knowledge, imagination, emotional mind towards a tourist spot [5]. Whereas [17] there is another opinion that destination image is a belief in tourists that related to products both will and have been purchased by tourists. This destination image does not only come from experience or truth but also comes from motivation that is able to encourage tourists to travel to a tourist spot [18].

On the other hand, [5] explains that there are several factors that trigger the emergence of a destination image, namely psychological characteristics, experience, media information such as (television, newspapers, books, etc.), motivation, social and economic characteristics, education level, marketing activities tourism and perception.

Destination image includes functional attitudes in which it relates to the reality that exists in tourism objects and also includes psychological attitudes that cannot be seen directly because they are not visible [2].This destination image is measured by two indicators, including (1) Cognitive imagery, that is, the beliefs and information a person has regarding a tourist destination; (2) Affective imagery, which is an emotional picture and a person's feelings for a tourist destination. 


\subsection{Destination Branding}

Destination branding is interpreted as a name, symbol, logo, or something else that is used to explain and differentiate a tourist place from one another, and can also be explained as a promising thing related to a tourist place because of the uniqueness possessed to improve even maintain tourist memories of a tourist spot [6]. One way that can be used to strengthen brands, especially destination branding, is to innovate products offered to tourists consistently so that they can compete in the same market share and improve service quality in order to increase visitor satisfaction, which both of these will have an impact on the interest of tourists is getting stronger to visit.According to [19] that these two things must be considered and improved by the management of tourism objects in order to have strong and superior branding compared to other tourist objects.

According to [6] that the strategy in destination branding is as follows (1) Brand Positioning, which is related to what will be done to the prospect's mind; (2) Brand Identity, which is providing brand-related information such as background, principles, goals, and desires; (3) Brand personality, namely to provide added value beyond consumer perceptions; and (4) Brand communication, which is conveying brand information to consumers in several ways such as sales promotions, events, public relations, sponsorship, and security. According to [6] the destination branding process consists of (1) market investigation, analysis, and strategic recommendations; (2) Development of brand identity; (3) Brand launch and introduction; (4) Brand implementation; and (5) Brand control and evaluation.

Destination branding can be measured using seven indicators including (1) Image, which is how tourists perceive a brand from a tourist place; (2) Recognition, namely an effort made to introduce tourist attractions; (3) Differentiation, namely its own uniqueness which is owned by a tourist place as a differentiator from other tourist attractions; (4) Brand Messages, namely the message delivered can create a positive image of tourists; (5) Consistency, which is consistent with the message conveyed related to tourist attractions; (6) Emotional Response, efforts made to generate emotional response from tourists; and (7) Creating Expectation, namely the formation of tourist expectations about the experience gained from a tourist place.

\section{Theoretical Framework and Proposition}

\subsection{Word of Mouth to Visit Intention}

The increasing age of a person, of course, also increases one's sociality with other people and their environment. It also has an impact on a person's lifestyle in considering something, one of which is considering the tourism objects that will be visited. In addition, this is in accordance with Indonesian culture which is happy to gather in a community, giving rise to the exchange of various information. This exchange of information is commonly known as word of mouth (WOM).

Word of Mouth (WOM) is a communication that takes place between one person and another person, neighbors, friends, family, and colleagues as a product-related target [20]. [4]also argues that WOM is a process of exchanging information related to products between one person and another which occurs freely without the bond of the company. According to [1] that with the existence of WOM, one can minimize doubts by seeking information from other people regarding a product that will be purchased by making decisions after obtaining that information. 
In addition, the WOM communication process is also a marketing strategy that refers to someone's recommendations to other people regarding a particular tourist attraction, which is the process of influencing others and has an impact on the intention of those affected to follow the recommendations received. WOM is considered very important if the recommended tourist object has good value or an attractive impression for tourists. Therefore, WOM can attract the intention of tourists to visit.

The statement is in accordance with the research conducted by [1] with the title "Analysis of the Effect of City Branding and Word of Mouth on Visiting Intentions and Its Impact on Decisions to Visit Sukabumi", which gave results that word of mouth was able to attract tourists to visit. Thus the propositions can be drawn as follows:

P1: Word of Mouth Can Attract Visit Intentions

\subsection{Destination Image to Visit Intention}

According to[5] that destination with a strong image as a differentiator from another destination, especially if the image is a positive image. In addition, according to [21] that destination with image and trustworthiness has a value of security and welfare for tourists. Therefore, image as one of the elements that are very important especially on tourism objects.[5] explains that a destination image is a form of overall appearance that arises from one's prejudice, knowledge, imagination, emotional thoughts towards a tourist spot. This destination image consists of two main components, namely cognitive image and affective image [5].

Cognitive image is the belief and information that someone has regarding a tourist spot [22]. This cognitive image consists of six elements including tourist attractions, basic facilities, cultural attractions, accessibility, and tourism substructure, natural environment, and economic factors. While the effective image is an emotional picture and a person's feelings towards a tourist spot [23]. This effective image consists of three elements including a vibrant city, a vibrant city, and a pleasant city. A tourist place that has a good image, it can attract even increase the intention of tourists to visit.

The statement is in accordance with the research conducted by [2] with the title "The Influence of the Sermo Reservoir Tourism Destination Image Against the Intention of Tourist Visits", which gives the result that the image of a tourism destination is able to attract tourists to visit the tourist attraction of Sermo Reservoir.Thus the propositions can be drawn as follows:

P2: Destination Image Can Attract Visit Intentions

\subsection{Destination Branding to Visit Intention}

In addition to the image, a brand is a tourist attraction also plays an important role in the world of marketing. This is also because the brand is a differentiator of a particular tourist attraction with other tourist objects [6]. A tourist attraction with a strong brand can certainly excel compared to other attractions.Destination branding is interpreted as a name, symbol, logo, or something else that is used to explain and differentiate a tourist place from one another, and can also be explained as a promising thing related to a tourist place because of the uniqueness possessed to improve even maintain tourist memories of a tourist spot [6]. Therefore, destination branding is very important to attract tourists to make a visit to a tourist place because it forms the perception that exists in tourists.

The statement is in accordance with the research conducted by [6] with the title "Analysis of the West Nusa Tenggara Province Destination Branding Program", which resulted in the 
destination branding program carried out in the province of West Nusa Tenggara (NTB) able to increase the intention of tourists to visit. Thus the propositions can be drawn as follows:

P3: Destination Branding Can Attract Visit Intentions

\subsection{Word of Mouth, Destination Image dan Destination Branding to Visit Intention}

According to [24] that the revenue mix is a collection of elements of the marketing manager's power in meeting the needs and desires of the consumers concerned. A good marketing mix strategy will affect the intentionof revisiting. Besides that, it is also accompanied by the word of mouth (WOM). WOM is a communication that occurs between one person and another person, neighbors, friends, family, and colleagues as a product-related target [20]. According to [1] that with the existence of WOM, one can minimize doubts by finding information from other people regarding a product that will be purchased by making a decision after obtaining that information.

Thus, WOM can influence the intention of tourists to visit. Besides the marketing mix and WOM, accompanied by the destination image. According to [5] that destination image is a manifestation of the overall appearance arising from prejudice, knowledge, imagination, one's emotional mind towards a tourist spot. This destination image does not only arise due to facts and experience but also arises because of a strong motivation in a person to visit a tourist spot [18].

The intentionof visiting tourists can also be influenced by destination branding. According to [6] that destination branding is a name, symbol, logo, or something else that is used to explain and differentiate a tourist place from one another, and can also be explained as a promising thing related to a tourist place because of its uniqueness in order to increase and even retain tourists' memories of a tourist place, so destination branding is very important to attract tourists to make a visit to a tourist spot because it forms the perception that exists in tourists. If a tourist attraction has a good marketing mix, raises a positive WOM, has a good image, and has a superior destination branding will certainly be able to attract and even increase the intention of tourists to visit.

Some of these statements are in accordance with several previous studies namely [1], [2] and [6] studies which gave results that WOM factors, destination image, and destination branding were able to attract tourists to visit, so that in this study these factors were analyzed to determine the impact on intention in visiting simultaneously. Thus the propositions can be drawn as follows:

P3: Word of Mouth, Destination Image dan Destination Branding Can Attract Visit Intentions

Based on the theoretical study above, the theoretical framework in this study is illustrated in the figure as follows: 


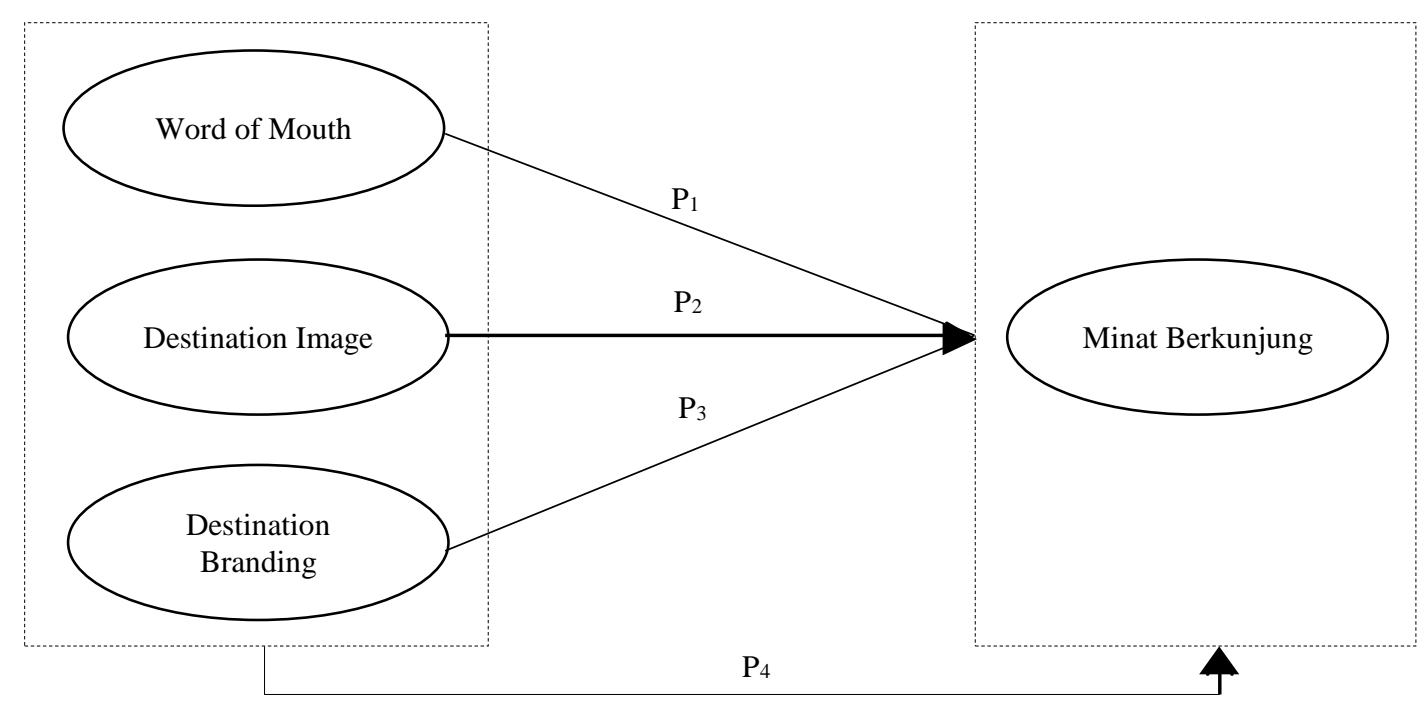

Figure 1: Theoritical Framework

\section{Research Method}

This section examines the approach taken to look deeper into the intention of tourist visits to coastal attractions. The approach is taken consists of five stages according to the advice given by [25]. The first stage refers to the scope of the research conducted, namely the urgency of the research conducted. The urgency of this research is seen by the existence of the most competitive business conditions in the field of tourism which in the global era are currently experiencing many developments. With competition in the tourism industry, each marine tourism business or local government needs to have the ability to increase tourists' intention in visiting tourist objects that have been developed, in order to face business competition in the current global era.

The second stage, identifying keywords. Selection of keywords is based on the topic specified. Some studies, referring to the influence of the marketing mix on visiting intentions. Other research also revealed the influence of word of mouth, destination image, and destination branding. Thus, the keywords chosen are the marketing mix, word of mouth, destination image, and destination branding as factors that influence the intention of visiting tourists. The third stage, previous research. This stage is carried out by selecting a number of literary sources that are in accordance with the specified topic.

The fourth stage, drawing conclusions from the results of previous studies. Based on the results of the analysis of several previous studies that discussed the topic specified, gave different results. Therefore, this research was carried out to develop the results of several previous studies. The fifth stage, determining the purpose of the study. This research has goals both empirically and practically. Empirically, it is used to develop and support the results of several previous studies. While practically, it is used to provide evaluations to marine tourism businesses related to marketing mix functions, word of mouth, destination image, and 
destination branding. As well as attracting and increasing intention in visiting local and international tourists.

\section{Conclusion}

The results of this review show an increasing intention in visiting tourists on coastal attractions. In this case, word of mouth, destination image, and destination branding are keys that can increase the visiting intention. This research was conducted with the aim of both empirically and practically. Empirically, namely the existence of differences from the results of several previous studies that discussed the topic specified. This is seen from the regression coefficient and coefficient of determination. Therefore, this study aims to develop results from previous studies. Whereas practically, namely to provide evaluations to marine tourism businesses related to the functions of word of mouth, destination image, and destination branding. As well as attracting and increasing intention in visiting local and international tourists.

\section{References}

[1] Abdulrahman, "Analisis Pengaruh City Branding dan Word Of Mouth Terhadap Minat Berkunjung Serta Dampaknya Terhadap Keputusan Berkunjung Ke Sukabumi," Universitas Islam Negeri Syarif Hidayatullah, 2018.

[2] Handawan, "Pengaruh Citra Destinasi Pariwisata Waduk Sermo Terhadap Minat Wisatawan Berkunjung Ulang," Universitas Negeri Yogyakarta, 2015.

[3] Ramadhan, "Pengaruh City Branding Terhadap Minat Berkunjung Serta Dampaknya Pada Keputusan Berkunjung (Survei Pada Wisatawan Kota Surabaya 2015)," J. Adm. Bisnis, vol. 28, no. 2, 2015.

[4] Silverman, The Secret Of Word of mouth Marketing How To Trigger Exponential Sales Through Runway Word of mouth. New York: Amacon, 2011.

[5] Lopes, "Destination Image: Origins, Developments and Implications," Rev. Tur. Patrim. Cult., 2011.

[6] Rahardhipa, "alisis Program Destination Branding Provinsi Nusa Tenggara Barat," J. Ilmu Adm. Bisnis, vol. 5, no. 1, 2016.

[7] M. Ali and Z. Ismail, "Assessing student teachers' understanding of the biology syllabus through concept mapping," in st Int. Conf. on Concept Mapping, 2004, pp. 53-58.

[8] Purnamasari, "Persepsi Wisatawan Domestik Tentang Unsur-Unsur Pembentu City Branding Kota Semarang Terhadap Minat Berkunjung Kembali ke Kota Semarang," Universitas Diponegoro, 2014.

[9] J. E. Ormrod, E. M. Anderman, and L. H. Anderman, Educational psychology: developing learners. New Jersey: Person Education Inc, 2003.

[10] Kotler dan Keller, Manajemen Pemasaran. Jakarta: Erlangga, 2009.

[11] Rizka, "Persepsi Konsumen Tentang Wisata Syariah dan Pengaruhnya Terhadap Minat Berkunjung," Universitas Lampung, 2016.

[12] Asdi, "Pengaruh Bauran Pemasaran Terhadap Minat Kunjungan Wisatawan Pada Obyek Wisata Alam Malino di Kabupaten Gowa," J. Ilm. Pena, vol. 1, no. 1, 2018.

[13] Kotler and Keller, Marketing Management, 14, Global ed. Pearson Prentice Hall, 2012.

[14] Gartika, Silaturahim Marketing. Jakarta: PT Gramedia Pustaka Utama, 2010.

[15] A. Yanu and A. Fianto, “ANTECEDENTS OF CUSTOMER SATISFACTION FOR 
SMALL MEDIUM,” Int. J. Civ. Eng. Technol., vol. 9, no. 11, pp. 2691-2702, 2018.

[16] D. Godes and D. Mayzlin, "Using Online Conversations to Study Word of Mouth Communication," SSRN Electron. J., vol. 23, 2002.

[17] Pitana dan Diarta, Pengantar Ilmu Pariwisata. Yogyakarta: Andi Offset, 2009.

[18] Hanif, "Pengaruh Citra Destinasi Terhadap Kepuasan Wisatawan Serta Dampaknya Terhadap Loyalitas Wisatawan ke Kota Batu," J. Adm. Bisnis, vol. 38, no. 1, pp. 4452, 2016.

[19] A. Y. Alif Fianto, D. Hadiwidjojo, S. Aisjah, and S. Solimun, "The Influence of Brand Image on Purchase Behaviour Through Brand Trust," Bus. Manag. Strateg., vol. 5, no. 2, p. 58, Sep. 2014.

[20] Kotler and Amstrong, Principles of Marketing, 13th ed. New Jersey USA: Pearson Education, 2010.

[21] Fakeye, "Image Differences between Prospective, First-Time, and Repeat Tourists to the Lower Rio Grande Valley," J. Travel Res., vol. 30, no. 2, pp. 10-16, 1991.

[22] J. R. Situmorang, "Pemanfaatan internet sebagai new media dalam bidang politik, bisnis, pendidikan dan sosial budaya," J. Adm. Bisnis, vol. 38, no. 1, 2012.

[23] S. Artuğer, B. C. Çetinsöz, and İ. Kılıç, "The effect of destination image on destination loyalty: An application in Alanya," Eur. J. Bus. Manag., vol. 5, no. 13, pp. 124-136, 2013.

[24] Shinta, Manajemen Pemasaran, Cetakan Pe. Malang: Universitas Brawijaya Press, 2011.

[25] VomBrocke, "Merekonstruksi raksasa: tentang pentingnya ketelitian dalam mendokumentasikan pencari-an literatur," in Prosiding Konferensi Eropa tentang Sistem Informasi, 2009. 